\title{
DAYA SAING, EKUIVALEN TARIF, DAN FAKTOR-FAKTOR YANG MEMENGARUHI PERMINTAAN EKSPOR MINYAK SAWIT INDONESIA DI NEGARA OKI
}

\author{
(Competitiveness, Tariff Equivalent, and Factors Affecting the Demand of Indonesia \\ Palm Oil Exports to OIC Countries)
}

\author{
Ghina Saarah Nibras* dan Widyastutik** \\ Departemen Ilmu Ekonomi, Fakultas Ekonomi dan Manajemen, Institut Pertanian Bogor \\ Jl. Agatis Kampus IPB Darmaga, Bogor, Jawa Barat \\ *Email: ghisaani@gmail.com,**Email: widyastutik_ipb@yahoo.com
}

Diterima: 13 Mei 2019

Direvisi: 22 Agustus 2019

Diterbitkan: 31 Desember 2019

\begin{abstract}
Indonesia is the largest exporter of palm oil in the world. However, in recent years, Indonesian palm oil has been faced by several obstacles. Therefore, Indonesia is expected to be able to diversify the market, which making the Organization of Islamic Cooperation (OIC) member countries as aim export countries. This study aims to analyze the competitiveness of Indonesian palm oil, tariff equivalent, and factors that affect the demand of Indonesia's palm oil exports to 28 OIC countries. The methods used in this research are Export Products Dynamics (EPD) and panel data regression. Method of analysis to estimate tariff's equivalent is a gravity model. The result of the study shows that Indonesian palm oil has strong competitiveness in 15 OIC countries. In the other hand, Indonesian palm oil at other 13 OKI country occupy falling star, lost opportunity, and retreat position. It caused by many factors. Some OKI country able to produce palm oil and become producer of palm oil, and there are competitors in country of destination. The estimations results using the panel data regression method shows that Gross Domestic Product (GDP) per capita of the importing country, economic distance, price of exports, population of the importing country, and the real exchange rate have a significant effect on the volume of Indonesian palm oil exports to the OIC countries. The study also found that the non-tariff barriers imposed by the OIC countries on Indonesian palm oil are still low. The highest tariff equivalent import apllied by Benin, it reaches 19.67.
\end{abstract}

Keywords: tariff equivalent, EPD, Gravity Model, palm oil, volume exports

\begin{abstract}
Abstrak
Indonesia merupakan negara pengekspor minyak sawit terbesar di dunia. Namun, dalam beberapa tahun terakhir, minyak sawit Indonesia dihadapi oleh beberapa hambatan. Oleh karena itu, Indonesia diharapkan mampu melakukan diversifikasi pasar, salah satunya dengan menjadikan negara anggota Organisasi Kerja sama Islam (OKI) sebagai negara tujuan ekspornya. Penelitian ini bertujuan untuk menganalisis bagaimana daya saing, besarnya ekuivalen tarif, dan faktor-faktor yang memengaruhi permintaan ekspor minyak sawit Indonesia di 28 negara OKI. Metode yang digunakan adalah Export Products Dynamics (EPD) dan regresi data panel. Metode analisis untuk mengestimasi ekuivalen tarif adalah model gravity. Hasil penelitian menunjukkan bahwa minyak sawit Indonesia memiliki daya saing yang cukup kuat pada 15 negara OKI. Sedangkan, minyak sawit Indonesia pada 13 negara OKI lainnya menempati posisi falling star, lost opportunity, dan retreat. Hal ini disebabkan oleh beberapa faktor, di antaranya adanya beberapa negara OKI yang juga merupakan produsen dari minyak sawit, serta adanya kompetitor di negara tujuan. Hasil estimasi menggunakan metode regresi data panel menunjukkan bahwa Produk Domestik Bruto (PDB) per kapita negara importir, jarak ekonomi, harga ekspor, populasi, dan nilai tukar riil berpengaruh signifikan terhadap volume ekspor minyak sawit Indonesia ke negara OKI. Penelitian ini juga menemukan bahwa negara OKI memberlakukan hambatan nontarif terhadap minyak sawit Indonesia walaupun besarannya relatif rendah. Nilai ekuivalen tarif impor tertinggi dikenakan oleh negara Benin sebesar 19,67.

Kata kunci: ekuivalen tarif, EPD, Gravity Model, minyak sawit, volume ekspor
\end{abstract}

\section{PENDAHULUAN}

Globalisasi tidak hanya dirasakan dampaknya pada bidang sosial budaya, tapi juga perekonomian, khususnya perdagangan. Salah satu dampak globalisasi dalam sektor perekonomian adalah semakin mudahnya melakukan perdagangan antarnegara, atau yang biasa disebut perdagangan internasional. Selain bentuk dari globalisasi, perdagangan internasional juga menunjukkan perekonomian yang semakin terbuka. Sistem perekonomian terbuka yang juga dianut oleh Indonesia menjadikan perdagangan internasional sebagai salah satu faktor yang menunjang pertumbuhan ekonomi. Salah satu upaya meningkatkan pertumbuhan ekonomi melalui perdagangan internasional dapat dilihat dari bergabungnya Indonesia pada beberapa organisasi maupun perjanjian perdagangan internasional seperti Asia Pasific Economic Cooperation (APEC), ASEAN-China Free Trade Agreement (ACFTA), Regional Comprehensive Economic Partnership (RCEP), Organisasi Kerja sama Islam (OKI), dan lainlain.

Sebagaimana negara lainnya, salah satu tujuan perdagangan bebas yang dilakukan Indonesia adalah 


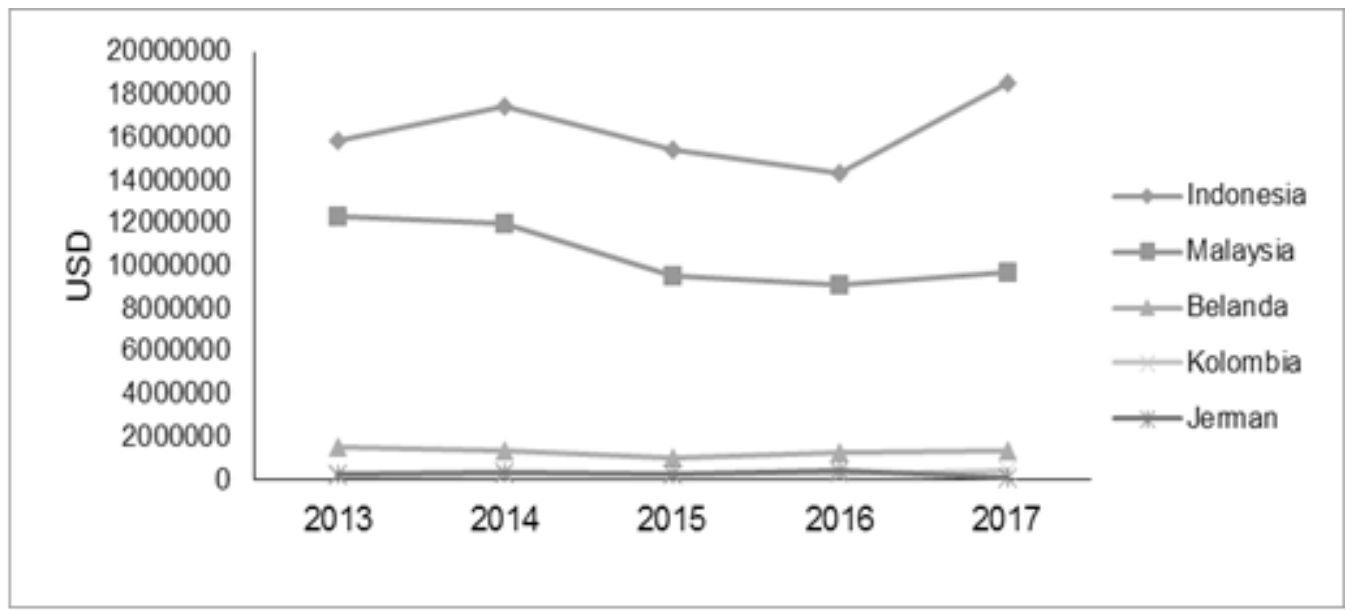

Sumber: ITC Trademap, 2019¹.

Gambar 1. Perkembangan Nilai Ekspor Minyak Sawit dari 5 Eksportir Utama ke Dunia Tahun 2013-2017

untuk meningkatkan pendapatan negara melalui ekspor. Berdasarkan Gambar 1, Indonesia merupakan negara eksportir minyak sawit (HS 1511) terbesar di dunia diikuti Malaysia, Belanda, Kolombia, dan Jerman. Hal ini merupakan peluang bagi Indonesia untuk menjadikan minyak sawit sebagai ekspor unggulan. Selain itu, perkembangan nilai ekspor minyak sawit Indonesia cenderung meningkat.

Upaya meningkatkan kinerja ekspor juga dapat dilakukan dengan melakukan diversifikasi pasar. Berdasarkan Gambar 2, dapat dilihat bahwa dari 5 besar negara tujuan ekspor minyak sawit Indonesia dengan kode HS 1511 masih didominasi oleh India dan China dengan volume ekspor terbesar. Didominasinya ekspor Indonesia pada beberapa negara menunjukkan bahwa Indonesia perlu melakukan diversifikasi pasar. Selain sebagai upaya meningkatkan kinerja ekspor, diversifikasi pasar juga diperlukan untuk menghindari ketergantungan terhadap pasar tradisional. Salah satu upaya perluasan pasar tujuan ekspor yang dapat dilakukan oleh Indonesia adalah dengan menjadikan negaranegara yang tergabung dalam OKI menjadi negara tujuan ekspor. Hal inijuga diperkuat dengan masuknya Pakistan dan Bangladesh yang merupakan anggota OKI dalam 5 besar negara tujuan ekspor minyak sawit Indonesia (BP3-Kementerian Perdagangan, 2018).

OKI adalah organisasi yang dibentuk tahun 1969 yang hingga saat ini beranggotakan 57 negara dengan penduduk mayoritas muslim yang berada di kawasan Afrika, Timur Tengah, Asia, dan Amerika Selatan. Berdasarkan Tabel 1 dapat dilihat bahwa minyak sawit dengan kode HS 151190 (Palm oil and its fractions, whether or not refined (excluding chemically modified)) menjadi komoditas ekspor utama Indonesia ke negara OKI tersebut.

Berdasarkan Gambar 3, selain minyak sawit, komoditas utama ekspor Indonesia ke negara OKI adalah komoditas HS 27 (batu bara). Hal ini menunjukkan bahwa OKI menjadi salah satu pasar

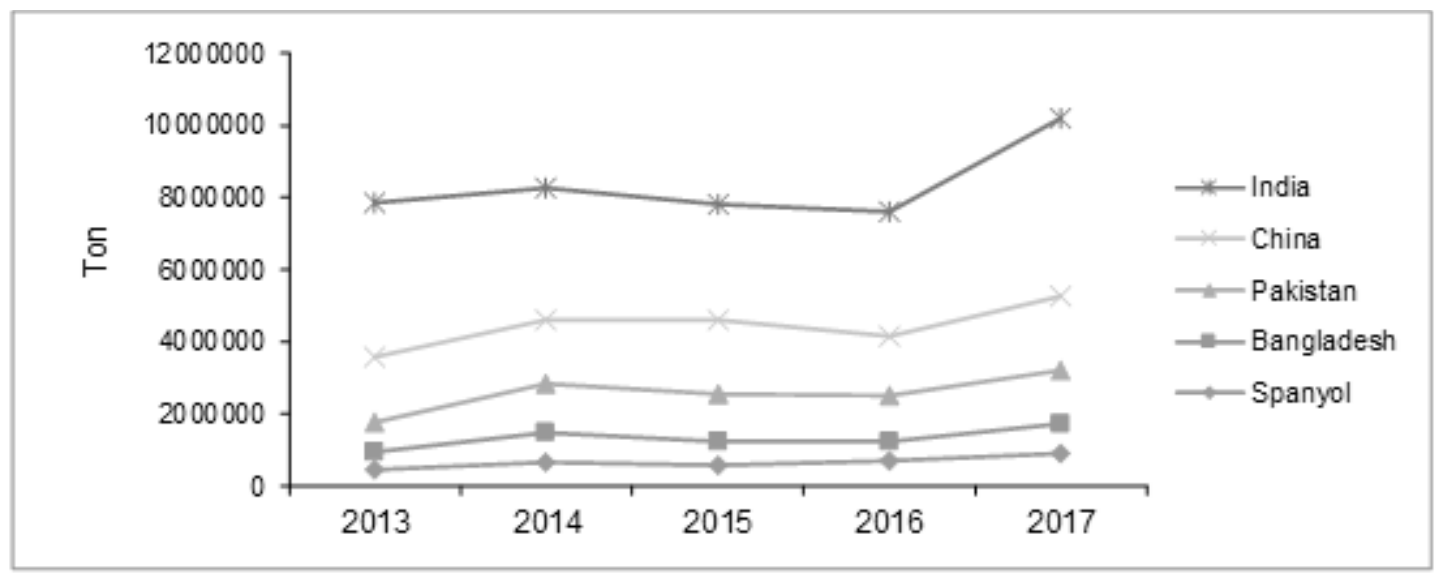

Sumber: ITC Trademap, $2019^{2}$.

Gambar 2. Volume Ekspor Minyak Sawit Indonesia ke 5 Besar Negara Tujuan Tahun 2013-2017

Data tersedia di ITC Trademap (www.trademap.org), diunduh pada Januari 2019.
Data tersedia di ITC Trademap (www.trademap.org), diunduh pada Januari 2019. 


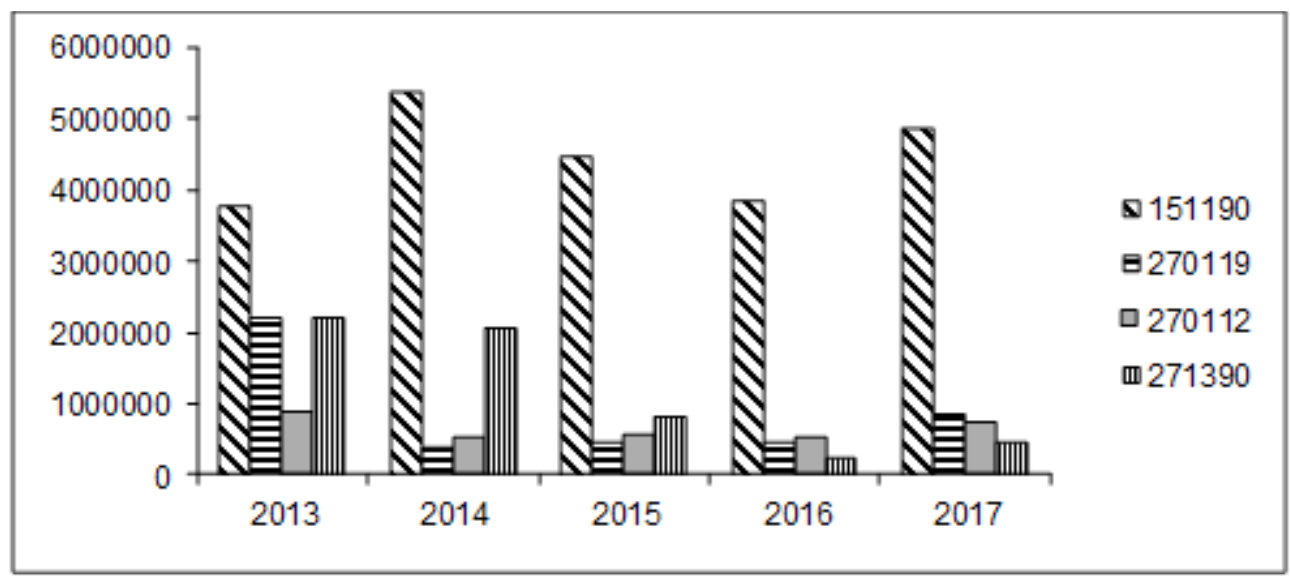

Sumber: ITC Trademap, $2019^{3}$

Gambar 3. Nilai Ekspor Komoditas Utama Ekspor Indonesia ke OKI Tahun 2013-2017

minyak sawit yang potensial bagi Indonesia. Tingginya nilai ekspor minyak sawit Indonesia ke negara OKI dapat dipengaruhi oleh beberapa faktor, salah satunya adalah kebutuhan minyak sawit yang tinggi dikarenakan biaya produksi yang murah. Menurut Lam, et al (2001), biaya produksi minyak sawit adalah sekitar €200 per ton, sedangkan biaya produksi minyak kanola (rapeseed oil) adalah dua kali lipat dari minyak sawit. Maka, minyak sawit merupakan komoditas yang banyak digunakan sebagai sumber energi dan makanan dibanding dengan jenis minyak nabati lainnya.

Sebagai negara produsen minyak sawit terbesar di dunia, Indonesia mampu menjadikan minyak sawit menjadi salah satu komoditas unggulan ekspor Indonesia ke negara OKI. Berdasarkan Tabel 1, minyak sawit Indonesia di negara OKI secara keseluruhan memiliki daya saing yang kuat berdasarkan hasil perhitungan Revealed Comparative Advantage (RCA). Hal ini dilihat dari keseluruhan nilai RCA yang lebih dari 1. Meskipun memiliki daya saing yang kuat, nilai RCA minyak sawit Indonesia mengalami fluktuasi bahkan penurunan pada beberapa negara. Adanya kecenderungan penurunan keunggulan suatu produk dapat dipengaruhi oleh beberapa faktor, salah satunya adalah ketidakjelian dalam membaca dinamika pasar, khususnya pasar luar negeri. Ketidakjelian tersebut mencakup perubahan selera, perkembangan teknologi, maupun berbagai kebijakan di negara tujuan ekspor yang bersifat protektif, serta perubahan-perubahan yang berlangsung dalam lingkungan ekonomi dan politik internasional (Basri \& Munandar, 2010).

Kebijakan di negara tujuan ekspor yang bersifat protektif merupakan salah satu faktor yang memengaruhi penurunan daya saing. Salah satu bentuk proteksi yang diterapkan oleh negara

Data tersedia di ITC Trademap (www.trademap.org), diunduh pada Januari 2019. importir adalah hambatan nontarif. Sebagaimana kesepakatan General Agreement on Tariff and Trade (GATT)/World Trade Organization (WTO) berupa pengurangan penerapan hambatan tarif maka hambatan nontarif lebih banyak diterapkan oleh suatu negara sebagai bentuk proteksi terhadap impor yang masuk ke negaranya. Ketika tingkat tarif di berbagai negara diturunkan secara berarti melalui serangkaian negosiasi perdagangan baik bilateral, regional bahkan multilateral, jumlah dan peranan berbagai bentuk hambatan perdagangan nontarif justru melonjak (Salvatore, 2007). Hambatan diterapkan oleh negara importir sebagai salah satu upaya dalam melindungi industri domestik. Adanya kecenderungan untuk melindungi pelaku usaha domestik memunculkan hambatan yang diterapkan terhadap komoditas yang akan diimpor. Pergeseran bentuk hambatan perdagangan tersebut berdampak pada perdagangan komoditas bilateral, regional, dan multilateral. Oleh karena itu, pada penelitian ini akan dianalisis mengenai bagaimana tingkat daya saing, faktor-faktor yang memengaruhi permintaan ekspor minyak sawit Indonesia ke negara OKI, serta besarnya hambatan nontarif yang diberlakukan oleh negara OKI terhadap minyak sawit Indonesia.

\section{METODE}

\section{Export Product Dynamics (EPD)}

Pada penelitian ini, metode Exports Products Dynamics (EPD) merupakan metode yang digunakan untuk menganalisis daya saing minyak sawit Indonesia ke negara OKI selama tahun 2013-2017, sedangkan analisis regresi data panel digunakan untuk menganalisis faktor-faktor yang memengaruhi permintaan ekspor minyak sawit Indonesia ke negara OKI, dan mengestimasi besarnya nilai hambatan nontarif yang diberlakukan negara importir.

EPD digunakan untuk mengidentifikasi produk yang kompetitif dan dinamis (pertumbuhannya 
Tabel 1. RCA Minyak Sawit Indonesia di Negara OKI Tujuan Utama Tahun 2013-2017

\begin{tabular}{|c|c|c|c|c|c|c|}
\hline \multirow{2}{*}{ Negara } & \multicolumn{6}{|c|}{ RCA } \\
\hline & 2013 & 2014 & 2015 & 2016 & 2017 & Rataan \\
\hline Afghanistan & 97,48 & 62,25 & 30,36 & 3,23 & 6,83 & 40,03 \\
\hline Algeria & 47,06 & 54,35 & 53,26 & 55,78 & 40,70 & 50,23 \\
\hline Bangladesh & 20,97 & 22,62 & 24,18 & 22,74 & 23,28 & 22,76 \\
\hline Benin & 4,66 & 10,91 & 13,81 & 9,27 & 9,08 & 9,54 \\
\hline Brunei Darussalam & 11,77 & 10,79 & 13,57 & 7,39 & 7,68 & 10,24 \\
\hline Burkina Faso & 115,62 & 125,21 & 10,08 & 3,00 & 10,76 & 52,93 \\
\hline Kamerun & 105,39 & 72,66 & 76,40 & 101,84 & 143,10 & 99,88 \\
\hline Gabon & 64,07 & 45,41 & 44,19 & 44,88 & 34,54 & 46,62 \\
\hline Gambia & 17,83 & 17,49 & 18,34 & 21,71 & 15,57 & 18,19 \\
\hline Guinea & 41,36 & 44,60 & 56,02 & 24,29 & 30,81 & 39,42 \\
\hline Guinea Bissa & 16,28 & 17,89 & 11,44 & 18,95 & 17,22 & 16,35 \\
\hline Iran & 42,03 & 63,51 & 51,89 & 31,03 & 11,81 & 40,05 \\
\hline Yordania & 34,88 & 29,10 & 33,16 & 40,82 & 57,71 & 39,14 \\
\hline Malaysia & 18,37 & 20,12 & 21,35 & 16,26 & 19,45 & 19,11 \\
\hline Maldives & 12,81 & 9,20 & 11,45 & 9,64 & 5,17 & 9,65 \\
\hline Mauritania & 28,82 & 24,06 & 23,73 & 19,13 & 15,51 & 22,25 \\
\hline Mesir & 38,56 & 44,81 & 49,84 & 49,27 & 40,10 & 44,51 \\
\hline Nigeria & 73,92 & 51,49 & 37,76 & 18,53 & 13,53 & 39,05 \\
\hline Oman & 79,73 & 81,15 & 96,82 & 103,46 & 58,25 & 83,88 \\
\hline Pakistan & 11,19 & 13,80 & 15,95 & 15,71 & 14,21 & 14,17 \\
\hline Saudi Arabia & 62,21 & 47,28 & 52,54 & 43,01 & 11,86 & 43,38 \\
\hline Senegal & 51,71 & 47,42 & 35,85 & 23,14 & 32,24 & 38,07 \\
\hline Sierra Leone & 34,82 & 36,95 & 43,82 & 32,82 & 33,86 & 36,45 \\
\hline Togo & 32,29 & 41,87 & 58,08 & 71,55 & 42,73 & 49,31 \\
\hline Tunisia & 233,69 & 260,11 & 256,45 & 351,94 & 295,42 & 279,52 \\
\hline Turki & 103,28 & 99,40 & 15,52 & 4,85 & 30,47 & 50,70 \\
\hline Uni Emirat Arab & 70,27 & 62,08 & 70,36 & 87,82 & 90,03 & 76,11 \\
\hline
\end{tabular}

cepat) dalam ekspor suatu negara. Metode EPD digunakan untuk mengidentifikasi apakah produk suatu negara mempunyai performa yang dinamis (pertumbuhannya cepat) atau tidak. Dengan pendekatan ini kinerja dari produk-produk ekspor negara di dunia dapat dibandingkan. Jika pertumbuhan suatu produk di atas rata-rata secara kontinu selama periode yang panjang maka produk tersebut mungkin dapat menjadi sumber pendapatan ekspor yang besar bagi negara tersebut
(Samosir, 2015). Terdapat empat kategori daya saing dalam analisis EPD, yaitu rising star, falling star, lost opportunity, dan retreat (Tabel 2).

Untuk melakukan analisis EPD dapat menggunakan rumus sebagai berikut:

Sumbu x:

Pertumbuhan pangsa pasar ekspor

$i=\frac{\sum_{t=1}^{i}\left(\frac{X i n}{X_{n}}\right)_{t} \times 100 \%-\sum_{t=1}^{i}\left(\frac{X i n}{X n}\right)_{t-1} \times 100 \%}{T}$

Tabel 2. Posisi Produk pada Hasil Estimasi EPD

\begin{tabular}{|c|c|c|}
\hline \multirow{2}{*}{ Share of Country's Export in World Trade } & \multicolumn{2}{|c|}{ Share of Product in World Trade } \\
\hline & Rising (Dynamic) & Falling (Stagnant) \\
\hline Rising (Competitive) & Rising Star & Falling Star \\
\hline Falling (Non-Competitive) & Lost Opportunity & Retreat \\
\hline
\end{tabular}


Sumbu y:

Pertumbuhan pangsa pasar produk

$n=\frac{\sum_{t=1}^{t}\left(\frac{x_{n}}{x}\right)_{t} \times 100 \%-\sum_{t}^{t=1}\left(\frac{X_{n}}{x}\right)_{t-1} \times 100 \%}{\tau}$

Di mana $x$ adalah volume ekspor, $T$ adalah jumlah tahun, dan $t$ adalah tahun ke $t$.

\section{Metode Analisis}

Regresi data panel digunakan untuk menganalisis laju perdagangan antarnegara secara makro. Variabel yang digunakan adalah PDB per kapita negara tujuan, jarak ekonomi, populasi negara tujuan, nilai tukar, dan harga ekspor. Estimasi model ditransformasikan dalam bentuk logaritma natural untuk memenuhi uji asumsi klasik, dan menghindari risiko bias sehingga diperoleh model yang akan digunakan adalah sebagai berikut:

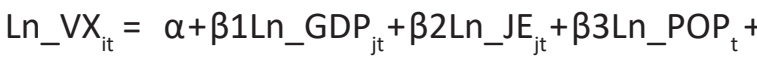

$$
\begin{aligned}
& \beta 4 \mathrm{Ln}_{-} R E R_{\mathrm{jt}}+\beta 5 \mathrm{Ln}_{-} \mathrm{HE}_{\mathrm{jt}}+\varepsilon_{\mathrm{ijt}}
\end{aligned}
$$

Di mana:

$$
\begin{array}{ll}
\mathrm{VX}_{\mathrm{it}} \quad: \begin{array}{l}
\text { volume ekspor minyak sawit Indonesia } \\
\text { ke negara tujuan (juta USD) }
\end{array} \\
\mathrm{GDP}_{\mathrm{jt}}: \begin{array}{l}
\text { GDP per kapita negara tujuan ekspor } \\
\text { pada tahun ke } t \text { (USD) }
\end{array} \\
\mathrm{JE}_{\mathrm{it}} \quad \begin{array}{l}
: \text { jarak ekonomi antarnegara Indonesia } \\
\text { dan negara tujuan (km) }
\end{array} \\
\mathrm{POP}_{\mathrm{jt}} \quad: \begin{array}{l}
\text { : populasi negara tujuan ekspor pada } \\
\text { tahun ke } t \text { (juta jiwa) }
\end{array} \\
\mathrm{NT}_{\mathrm{jt}} \quad: \begin{array}{l}
\text { nilai tukar riil mata uang negara tujuan } \\
\text { (mata uang negara tujuan/Rupiah) }
\end{array} \\
\mathrm{HE}_{\mathrm{jt}} \quad: \begin{array}{l}
\text { harga ekspor negara tujuan ekspor pada } \\
\text { tahun ke } t \text { (juta jiwa) }
\end{array} \\
\mathrm{e}_{\mathrm{ijt}} \quad: \text { error term } \\
\alpha \quad: \text { intercept } \\
\beta \mathrm{nn} \quad: \text { slope }(\mathrm{n}=1,2, \ldots)
\end{array}
$$

\section{Estimasi Perhitungan Hambatan NonTarif}

Setelah semua parameter diestimasi maka aliran perdagangan potensial dapat diperoleh dengan mensubtitusikan seluruh data ke dalam regresi data panel yang diestimasi. The fitted trade flows dari regresi data panel dispesifikasikan sebagai aliran perdagangan potensial. Perbedaan antara aliran perdagangan aktual dan potensial mengindikasikan ekuivalen tarif. Formula hambatan nontarif seperti yang dilakukan dalam studi Sari \& Widyastutik (2015), Anggoro \& Widyastutik (2016) mengacu pada Callaghan \& Uprasen (2008), yaitu:

$$
(T j-1)=\left(\frac{\frac{x a j}{x p j}}{\frac{x a b}{x p b}}\right)^{-\frac{1}{\varepsilon}}-1
$$

Di mana:

(Tj-1) : hambatan non-tarif negara untuk komoditas minyak sawit

Xaj : volume ekspor aktual masing-masing negara tujuan ekspor (ton)

Xpj : volume ekspor potensial masing-masing negara tujuan ekspor (ton)

Xab : volume ekspor aktual negara benchmark minyak sawit (ton)

$\mathrm{Xpb}$ : volume ekspor potensial negara benchmark minyak sawit (ton)

e : elastisitas substitusi minyak sawit Indonesia yang diperoleh berdasarkan hasil penelitian Ernawati, et al. (2006) menunjukkan elastisitas subtitusi minyak sawit bernilai 2,74. Elastisitas subtitusi komoditas digunakan untuk melihat besarnya pengaruh yang diberikan oleh hambatan perdagangan terhadap neraca perdagangan

\section{Data}

Penelitian ini menggunakan data sekunder, yaitu data panel yang terdiri dari data cross section dan time series volume ekspor minyak sawit Indonesia ke negara OKI dari tahun 2013-2017 untuk menganalisis daya saing, faktor-faktor yang memengaruhi, dan ekuivalen tarif impor. Data yang digunakan berasal dari beberapa sumber sebagaimana dijelaskan pada Tabel 3.

\section{HASIL DAN PEMBAHASAN}

Daya Saing Minyak Sawit Indonesia di Negara OKI

Perdagangan internasional menjadi sesuatu yang tidak bisa diabaikan kontribusinya terhadap

Tabel 3. Jenis dan Sumber Data

\begin{tabular}{lll}
\hline \multicolumn{1}{c}{ Jenis Data } & Sumber & Satuan \\
\hline Volume dan nilai ekspor minyak sawit & WITS & USD Juta \\
\hline GDP per kapita & World Bank & USD Juta \\
\hline Nilai tukar & UNCTAD & Rp/LCU \\
\hline Jarak geografis & CEPII & $\mathrm{Km}$ \\
\hline Populasi & World Bank & Juta Jiwa \\
\hline
\end{tabular}


Tabel 4. Hasil Estimasi EPD Ekspor Minyak Sawit Indonesia ke Negara OKI Posisi Rising Star

\begin{tabular}{lccc}
\hline \multicolumn{1}{c}{ Importir } & $\begin{array}{c}\text { Pertumbuhan Pangsa Pasar } \\
\text { Produk (Persen) }\end{array}$ & $\begin{array}{c}\text { Pertumbuhan Pangsa Pasar } \\
\text { Ekspor (Persen) }\end{array}$ & Posisi EPD \\
\hline Afghanistan & 8,06 & 2,89 & Rising Star \\
\hline Algeria & 1,42 & 8,26 & Rising Star \\
\hline Bangladesh & 7,25 & 4,04 & Rising Star \\
\hline Benin & 148,99 & 63,26 & Rising Star \\
\hline Brunei Darussalam & 2,62 & 15,99 & Rising Star \\
\hline Burkina Faso & 35,72 & 1,66 & Rising Star \\
\hline Mesir & 7,21 & 6,57 & Rising Star \\
\hline Yordania & 19,90 & 1,30 & Rising Star \\
\hline Malaysia & 4,11 & 0,57 & Rising Star \\
\hline Oman & 6,23 & 16,75 & Rising Star \\
\hline Pakistan & 15,99 & 7,85 & Rising Star \\
\hline Senegal & 6,57 & 11,35 & Rising Star \\
\hline Sierra Leone & 12,78 & 14,16 & Rising Star \\
\hline Togo & 32,06 & 29,71 & Rising Star \\
\hline Uni Emirat Arab & 12,37 & 8,04 & Rising Star \\
\hline
\end{tabular}

Sumber: UN Comtrade, 2019 (diolah).

perekonomian. Interaksi antar negara yang semakin terbuka menjadi sebuah peluang bagi setiap negara dalam meningkatkan kinerja perdagangan. Perdagangan internasional membuka kesempatan bagi setiap negara agar mampu mencapai kondisi economy of scale dan selanjutnya dapat menyalurkan kelebihan produksi yang tidak dapat diserap oleh konsumen di dalam negeri melalui ekspor (Basri \& Munandar, 2010).

Indonesia merupakan negara pengekspor minyak sawit utama ke negara OKI. Untuk dapat mengoptimalkan kinerja ekspornya, Indonesia perlu mengetahui kinerja minyak sawit Indonesia pada pasar negara OKI dan kemudian menentukan pasar yang potensial untuk dikembangkan. Kinerja ekspor suatu komoditas suatu negara dapat dinilai dengan EPD. Nilai EPD menunjukkan bagaimana pertumbuhan produk pada arus perdagangan ekspor suatu negara.

Hasil estimasi EPD menunjukkan bahwa posisi minyak sawit Indonesia berada pada posisi Rising Star pada 15 negara OKI dari total 28 negara yang diteliti (Tabel 4). Posisi pasar rising star menunjukkan bahwa ekspor minyak sawit Indonesia berada pada posisi pasar tertinggi di mana pada posisi ini ekspor minyak sawit Indonesia mengalami peningkatan dan pangsa pasar atau permintaan ekspor minyak sawit di 15 negara OKI di atas juga mengalami peningkatan. Kondisi ini menunjukkan bahwa minyak sawit Indonesia memiliki dinamika perdagangan yang positif di 15 negara OKI. Hal ini sejalan dengan data yang dipublikasikan oleh ITC Trademap (2017), yang menunjukkkan bahwa Indonesia masih menjadi eksportir utama minyak sawit ke-15 negara tersebut.

Tingginya permintaan minyak sawit Indonesia pada 15 negara OKI dapat dipengaruhi oleh beberapa faktor. Di Afghanistan dan Pakistan, minyak sawit Indonesia diperlukan sebagai bahan baku pembuatan ghee. Sementara, ekspor minyak sawit Indonesia ke beberapa Negara Afrika disebabkan hasil panen jauh lebih rendah di Afrika daripada di Asia Tenggara karena berbagai alasan, termasuk iklim dan keterbatasan infrastruktur dan pendekatan petani kecil terhadap produksi.

Ekspor minyak sawit pada Negara Pantai Gading, Tunisia, dan Turki berada pada posisi lost opportunity

Tabel 5. Hasil Estimasi EPD Minyak Sawit Indonesia ke Negara OKI Posisi Lost Opportunity

\begin{tabular}{lccc}
\hline \multicolumn{1}{c}{ Importir } & $\begin{array}{c}\text { Pertumbuhan Pangsa Pasar } \\
\text { Produk (persen) }\end{array}$ & $\begin{array}{c}\text { Pertumbuhan Pangsa Pasar } \\
\text { Ekspor (persen) }\end{array}$ & Posisi EPD \\
\hline Pantai Gading & 10,88 & $-10,23$ & Lost Opportunity \\
\hline Tunisia & 3,54 & $-0,04$ & Lost Opportunity \\
\hline Turki & 92,67 & $-4,54$ & Lost Opportunity \\
\hline Sumber: UN Comtrade, 2019 (diolah). & & &
\end{tabular}


Tabel 6. Hasil Estimasi EPD Minyak Sawit Indonesia ke Negara OKI Posisi Falling Star

\begin{tabular}{lccc}
\hline \multicolumn{1}{c}{ Importir } & $\begin{array}{c}\text { Pertumbuhan Pangsa Pasar } \\
\text { Produk (persen) }\end{array}$ & $\begin{array}{c}\text { Pertumbuhan Pangsa Pasar } \\
\text { Ekspor (persen) }\end{array}$ & Posisi EPD \\
\hline Gabon & $-13,09$ & 0,41 & Falling Star \\
\hline Gambia & $-3,57$ & 1,74 & Falling Star \\
\hline Maldives & $-13,24$ & 3,43 & Falling Star \\
\hline Mauritania & $-8,38$ & 8,55 & Falling Star \\
\hline Saudi Arabia & $-22,92$ & 6,24 & Falling Star \\
\hline Sumber: UN Comtrade, 2019 (diolah). & & &
\end{tabular}

yang menunjukkan minyak sawit Indonesia telah kehilangan kesempatan untuk meningkatkan pangsa pasar ekspor di ketiga negara tersebut (Tabel 5). Pada posisi pasar lost opportunity, Indonesia tidak mampu memenuhi pangsa pasar ekspor di Pantai Gading, Tunisia, dan Turki meskipun permintaan pangsa pasar sawit di ketiga negara tersebut mengalami peningkatan.

Pangsa ekspor minyak sawit Indonesia yang turun di Negara Pantai Gading dikarenakan Pantai Gading juga merupakan produsen minyak sawit di Afrika Barat yang juga memiliki surplus minyak sawit yang cukup besar. Sedangkan, hilangnya pangsa ekspor minyak sawit di Tunisia disebabkan Tunisia yang merupakan salah satu produsen minyak zaitun terbesar. Hal ini mengakibatkan konsumsi minyak zaitun di Tunisia jauh lebih besar dibanding minyak sawit. Turunnya pangsa ekspor Indonesia di Turki disebabkan penurunan nilai ekspor minyak sawit Indonesia yang sangat signifikan semenjak tahun 2014. Turunnya nilai ekspor minyak sawit Indonesia ke Turki diikuti dengan Turki yang mulai mengimpor minyak sawit dari eksportir baru, yakni Malaysia seiring dengan adanya perjanjian Malaysia-Turki Free Trade Area (MTFTA).

Posisi lost opportunity merupakan posisi yang potensial bagi suatu negara untuk masuk ke dalam kategori rising star. Diperlukan beberapa upaya untuk meningkatkan kinerja ekspor Indonesia pada ketiga negara tersebut, di antaranya mempererat kerja sama dengan mitra dagang antara Indonesia dengan negara-negara Afrika mengingat masih minimnya perjanjian kerja sama yang dilakukan antara Indonesia dan negara di Benua Afrika. Selain itu, perlunya pembangunan infrastruktur ekspor guna meningkatkan kinerja dan mengurangi hambatan ekspor, penyelarasan regulasi, yang pada akhirnya akan membentuk harga yang kompetitif di pasar internasional.

Hasil estimasi EPD menunjukkan negara Gabon, Gambia, Maldives, Mauritania, dan Saudi Arabia berada pada posisi falling star, yaitu posisi di mana minyak sawit Indonesia telah kehilangan pangsa pasar produknya di kelima negara tersebut (Tabel 6). Hilangnya pangsa pasar produk di pasar Gabon, Gambia, Maldives, Mauritania, dan Saudi Arabia ini disebabkan perbandingan total ekspor Indonesia ke negara tersebut dengan total ekspor Indonesia ke negara lainnya cenderung mengalami penurunan. Hal ini menyebabkan Indonesia kehilangan kesempatan untuk meningkatkan pangsa pasar produknya di 5 negara tersebut.

Pada hasil estimasi untuk negara Kamerun, Guinea, Guinea-Bisseau, Iran, dan Nigeria menunjukkan bahwa minyak sawit Indonesia berada pada posisi Retreat (Tabel 7). Hal ini menunjukkan bahwa komoditas minyak sawit Indonesia kehilangan kesempatan untuk meningkatkan pangsa pasar ekspor dan pangsa pasar produk di lima negara tersebut. Posisi retreat juga dapat menunjukkan bahwa produk suatu negara sudah tidak diinginkan lagi di negara importirnya.

Penyebab hilangnya pasar ekspor Indonesia di negara Kamerun adalah pertumbuhan pangsa ekspor yang negatif selama tahun 2013 hingga tahun 2017. Turunnya nilai ekspor Indonesia ke

Tabel 7. Hasil Estimasi EPD Minyak Sawit Indonesia ke Negara OKI Posisi Retreat

\begin{tabular}{lccc}
\hline \multicolumn{1}{c}{ Importir } & $\begin{array}{c}\text { Pertumbuhan Pangsa Pasar } \\
\text { Produk (persen) }\end{array}$ & $\begin{array}{c}\text { Pertumbuhan Pangsa } \\
\text { Pasar Ekspor (persen) }\end{array}$ & Posisi EPD \\
\hline Kamerun & $-1,35$ & $-10,49$ & Retreat \\
\hline Guinea & $-2,67$ & $-8,86$ & Retreat \\
\hline Guinea Bisseau & $-8,82$ & $-12,23$ & Retreat \\
\hline Iran & $-27,36$ & $-0,38$ & Retreat \\
\hline Nigeria & $-36,74$ & $-4,61$ & Retreat \\
\hline
\end{tabular}

Sumber: UN Comtrade, 2019 (diolah). 
Kamerun disebabkan Kamerun yang juga merupakan produsen minyak sawit, yang menyebabkan nilai ekspor minyak sawit Indonesia ke Kamerun kecil. Selain itu, minyak sawit Indonesia juga berada pada posisi retreat di Guinea. Hal ini disebabkan Malaysia merupakan eksportir minyak sawit terbesar ke Guinea semenjak tahun 2010, yang kemudian diikuti dengan Singapura sebagai eksportir minyak sawit kedua setelah Malaysia ke Guinea. Sedangkan di GuineaBissau, produk bahan makanan dan elektronik masih menjadi produk utama yang diimpor oleh negara tersebut. Hal ini yang kemudian menyebabkan impor minyak sawit oleh Guinea-Bissau masih sangat rendah. Selain di Guinea, Malaysia, dan Singapura juga menjadi eksportir minyak sawit terbesar ke Iran. Sedangkan, nilai ekspor minyak sawit Indonesia ke Iran mengalami penurunan yang sangat signifikan semenjak tahun 2012. Sementara, hilangnya pasar ekspor minyak sawit di Nigeria disebabkan Nigeria juga merupakan produsen minyak sawit. Selain itu, nilai ekspor minyak sawit Indonesia ke Nigeria juga mengalami penurunan yang signifikan semenjak tahun 2014.

Indonesia diharapkan mampu mempertahankan posisi rising star pada ke-15 negara tersebut guna meningkatkan kinerja ekspor. Selain rising star, posisi lost opportunity merupakan posisi yang potensial untuk dijadikan sebagai pangsa tujuan ekspor. Bahkan jika memungkinkan, negara yang berada pada posisi lost opportunity dapat berpindah ke posisi rising star dengan beberapa upaya di antaranya adalah mempererat kerja sama dengan mitra dagang antara Indonesia dengan negara-negara OKI mengingat masih minimnya perjanjian kerja sama yang dilakukan antara Indonesia dan negara OKI. Selain itu, perlunya pembangunan infrastruktur ekspor guna meningkatkan kinerja dan mengurangi hambatan ekspor, penyelarasan regulasi, yang pada akhirnya akan membentuk harga yang kompetitif di pasar internasional.

Salah satu bentuk infrastruktur ekspor adalah infrastruktur transportasi. Berdasarkan penelitian Asikin, et al. (2016), infrastruktur transportasi negara tujuan, teknologi informasi dan telekomunikasi negara tujuan, tata kelola pemerintahan Indonesia, serta tingkat efisiensi perdagangan lintas batas antara negara tujuan dan Indonesia berpengaruh positif terhadap kinerja ekspor secara agregat. Infrastruktur transportasi merupakan salah satu penopang ekspor yang menentukan kelancaran distribusi barang. Perbaikan dalam infrastruktur transportasi Indonesia dan negara tujuan akan meningkatkan volume ekspor. Berdasarkan catatan Gabungan Pengusaha Makanan dan Minuman Indonesia (GAPMMI), salah satu tantangan ekspor bagi produk makanan dan minuman Indonesia ke Afrika adalah adanya tarif yang mahal dan biaya transportasi di wilayah Afrika yang juga masih mahal. Oleh sebab itu, tidak banyak yang dapat dilakukan oleh negara eksportir, termasuk Indonesia, kecuali menurunkan biaya produksi (unit cost) agar dapat tetap kompetitif meskipun harus menanggung biaya transportasi di negara tujuan ekspor. Membentuk hub ekspor merupakan salah satu upaya untuk meningkatkan daya saing di pasar ekspor, misalnya dengan memperbaiki infrastruktur dengan membentuk hub ekspor Indonesia di kawasan Afrika, Asia Selatan, dan Timur Tengah yang saat ini masih belum ada. Perbaikan infrastruktur ekspor diharapkan mampu dilakukan secara merata bagi wilayah perkotaan maupun regional guna mempermudah distribusi antar wilayah. Efisiensi dengan menurunkan biaya produksi (unit cost) merupakan syarat mutlak agar Indonesia memiliki daya saing di pasar ekspor meskipun harus menanggung biaya transportasi di negara tujuan ekspor. Dengan demikian maka terbentuk hub ekspor yang merupakan salah satu upaya untuk meningkatkan daya saing di pasar ekspor.

\section{Faktor-Faktor yang Memengaruhi Permintaan Ekspor Minyak Sawit Indonesia ke Negara OKI}

Estimasi model untuk mendapatkan model yang mampu menjelaskan faktor-faktor yang memengaruhi ekspor minyak sawit Indonesia ke negara OKI dilakukan dengan tiga pendekatan model, yakni dengan Pooled Least Square (PLS), Fixed Effect Model (FEM), dan Random Effect Model (REM). Penentuan model dilakukan melalui Uji Chow dan Uji Hausman pada Tabel 8.

Berdasarkan Tabel 8 hasil Uji Chow menunjukkan nilai probabilitas 0,0 kurang dari taraf nyata 5 persen sehingga cukup bukti untuk menolak $\mathrm{H}_{0}$. Oleh sebab itu, model FEM lebih baik digunakan dibanding model PLS. Hasil estimasi uji Hausman juga menunjukkan nilai 0,01 yang juga kurang dari taraf nyata 5 persen sehingga cukup bukti untuk menolak $\mathrm{H}_{0}$. Jadi, model FEM lebih baik digunakan dibanding model REM.

Berdasarkan hasil estimasi pada Tabel 9, didapatkan nilai $R^{2}$ sebesar 99,3 persen. Nilai ini menunjukkan bahwa 99,3 persen perubahan volume ekspor minyak sawit Indonesia ke negara OKI dapat dijelaskan oleh variabel PDB per kapita negara pengimpor, harga ekspor, jarak ekonomi,

Tabel 8. Hasil Uji Chow dan Uji Hausman

\begin{tabular}{lcc}
\hline Uji Model Terbaik & Nilai Probabillitas & Hasil Hipotesis \\
\hline Uji Chow & 0,00 & Tolak $\mathrm{H}_{0}$ maka FEM \\
Uji Hausman & 0,01 & Tolak $\mathrm{H}_{0}$ maka FEM \\
\hline
\end{tabular}


populasi negara pengimpor, nilai tukar riil, dan tarif. Sedangkan sisanya sebesar 0,7 persen dijelaskan oleh faktor lain di luar model.

Uji F-statistik dilakukan untuk mengetahui apakah variabel independen secara bersama-sama berpengaruh nyata terhadap variabel dependen pada taraf nyata 5 persen. Hasil estimasi pada Tabel 9, menunjukkan nilai probabilitas F-statistik sebesar 0,0 kurang dari taraf nyata 5 persen sehingga dapat disimpulkan bahwa ada setidaknya satu variabel eksogen yang berpengaruh signifikan terhadap perubahan volume ekspor minyak sawit Indonesia.

Uji t-statistik digunakan untuk mengetahui apakah koefisien masing-masing variabel independen memberikan pengaruh nyata terhadap variabel dependennya. Hasil estimasi pada Tabel 9, menunjukkan bahwa variabel eksogen, yakni PDB per kapita negara pengimpor, harga ekspor, jarak ekonomi, dan populasi negara pengimpor nyata 1 persen. Sedangkan nilai tukar riil memiliki nilai probabilitas kurang dari taraf nyata 10 persen. Hal ini menunjukkan bahwa variabel eksogen tersebut secara individu berpengaruh signifikan terhadap volume ekspor minyak sawit Indonesia.

Setelah melakukan estimasi, diperoleh model terbaik dengan pengolahan data panel pada fixed effect model dengan pembobotan cross section weights. Model ini merupakan model terbaik karena telah memenuhi uji asumsi klasik. Hasil estimasi model menunjukkan bahwa variabel PDB per kapita, jarak ekonomi, harga ekspor, dan populasi memiliki probabilitas di bawah $\alpha=5$ persen, sementara variabel nilai tukar riil memiliki probabilitas kurang dari $\alpha=10$ persen. Hal ini mengindikasikan bahwa variabel-variabel yang digunakan dalam model, berpengaruh nyata terhadap volume ekspor minyak sawit Indonesia ke negara OKI, dengan asumsi ceteris paribus. Berdasarkan hasil estimasi pada Tabel 9, didapatkan nilai $\mathrm{R}^{2}$ sebesar 99,3 persen. Nilai ini menunjukkan bahwa 99,3 persen perubahan permintaan ekspor minyak sawit Indonesia ke negara OKI dapat dijelaskan oleh variabel PDB per kapita negara pengimpor, harga ekspor, jarak ekonomi, populasi negara pengimpor, nilai tukar riil, dan tarif. Sedangkan sisanya sebesar 0,7 persen dijelaskan oleh faktor lain di luar model.

PDB per kapita negara importir memiliki pengaruh positif terhadap volume ekspor minyak sawit Indonesia ke negara OKI. Hasil estimasi pada Tabel 9 menunjukkan bahwa PDB per kapita negara pengimpor signifikan memengaruhi volume ekspor minyak sawit Indonesia pada taraf nyata 5 persen dengan nilai koefisien pada model sebesar 2,8. Hal ini mengindikasikan bahwa peningkatan PDB per kapita negara pengimpor sebesar 1 persen akan
Tabel 9. Hasil Estimasi Model Terbaik

\begin{tabular}{lcl}
\hline \multicolumn{1}{c}{ Variabel } & Koefisien & Prob. \\
\hline LN_GDKPT & 2,79 & $0,002^{*}$ \\
\hline LN_EDIST & $-3,81$ & $0,00^{*}$ \\
\hline LN_POP & $-5,24$ & $0,00^{*}$ \\
\hline LN_RER & 0,77 & $0,08^{* *}$ \\
\hline LN_HARGAEKS & $-0,39$ & $0,00^{*}$ \\
\hline C & 90,97 & 0,00 \\
\hline$R^{2}$ & & 0,99 \\
\hline Prob (F-statistic) & & 0,00 \\
\hline
\end{tabular}

Sumber: Hasil Olah Data.

Keterangan: * : signifikan pada taraf nyata 1 persen.

** : signifikan pada taraf nyata 10 persen.

meningkatkan permintaan ekspor minyak sawit Indonesia sebesar 2,8 persen, ceteris paribus. Hal ini sesuai dengan hipotesis yang menyatakan bahwa PDB per kapita negara pengimpor memiliki hubungan positif terhadap perdagangan.

Variabel lain yang juga memengaruhi volume ekspor adalah jarak ekonomi yang merupakan proksi biaya transportasi. Semakin jauh jarak antara dua negara yang berdagang akan menyebabkan biaya transportasi yang semakin mahal. Hasil estimasi menunjukkan bahwa jarak ekonomi berpengaruh signifikan pada taraf nyata 1 persen dengan koefisien sebesar $-3,8$. Nilai tersebut mengindikasikan bahwa semakin jauh jarak antara Indonesia dengan negara pengimpor sebesar 1 persen akan menurunkan ekspor minyak sawit sebesar 3,8 persen, ceteris paribus. Hasil penelitian ini sejalan dengan hipotesis penelitian yang menyatakan bahwa semakin jauh jarak antara negara importir dan negara tujuan, maka akan semakin rendah permintaan ekspor terhadap suatu komoditas. Jauhnya jarak antar negara yang saling berdagang menyebabkan semakin besar biaya yang digunakan untuk melakukan transaksi perdagangan sehingga mereduksi minat negara importir untuk membeli komoditas dari negara eksportir.

Hasil estimasi pada variabel populasi menunjukkan koefisien bertanda negatif dengan nilai sebesar -5,2 dan berpengaruh signifikan pada taraf nyata 1 persen. Tanda negatif pada variabel populasi menunjukkan bahwajika terjadi peningkatan populasi sebesar 1 persen, maka akan menurunkan permintaan ekspor sebesar 5,2 persen. Hasil studi ini tidak sesuai dengan teori maupun hipotesis penelitian. Adanya isu negatif terkait dengan masalah kesehatan pada produk CPO (CPO dianggap mengandung senyawa yang bersifat karsinogen) mendorong peningkatan populasi yang tidak disertai dengan peningkatan permintaan ekspor CPO Indonesia dari negara- 
negara OKI. Peningkatan populasi negara OKI hanya meningkatkan permintaan minyak nabati lainnya seperti minyak biji bunga matahari. Selain itu, minyak kedelai maupun zaitun juga menjadi komoditas subtitusi minyak sawit yang juga diimpor dalam jumlah besar oleh beberapa negara OKI. Adanya komoditas subtitusi ini menyebabkan peningkatan populasi dapat menurunkan permintaan ekspor komoditas lainnya, sehingga permintaan terhadap ekspor turun.

Hasil estimasi yang diperoleh model menunjukkan bahwa variabel nilai tukar rupiah terhadap negara pengimpor berpengaruh signifikan pada taraf nyata 10 persen dengan koefisien sebesar 0,8 . Hal ini mengindikasikan bahwa apabila terjadi peningkatan nilai nominal rupiah (depresiasi) terhadap negara pengimpor sebesar 1 persen, maka akan meningkatkan arus perdagangan ekspor sebesar 0,8 persen, ceteris paribus. Hasil ini sesuai dengan penelitian yang dilakukan oleh Zarzoso \& Lehmann (2003) yang menyatakan bahwa terjadinya depresiasi mata uang negara pengekspor akan mampu meningkatkan ekspor. Selain itu, hasil estimasi ini juga sesuai dengan penelitian Sari, et al. (2014) yang menyatakan apabila nilai tukar riil meningkat atau mata uang negara pengekspor terdepresiasi akan menyebabkan harga produk menjadi lebih murah sehingga mendorong permintaan negara tujuan.

Harga ekspor minyak sawit berpengaruh signifikan pada taraf nyata 1 persen. Hal ini menunjukkan bahwa salah satu variabel yang berpengaruh terhadap volume ekspor minyak sawit Indonesia adalah harga ekspor komoditas itu sendiri. Nilai koefisien harga ekspor minyak sawit Indonesia negatif sebesar 0,4 , yang artinya apabila ada kenaikan harga ekspor minyak sawit sebesar 1 persen maka volume ekspor akan turun sebesar 0,4 persen, ceteris paribus. Hasil estimasi ini sesuai dengan hipotesis penelitian yang mengatakan bahwa kenaikan harga ekspor akan menurunkan volume ekspor minyak sawit Indonesia. Sebagaimana dijelaskan pada teori permintaan, kenaikan harga ekspor akan menurunkan jumlah barang yang diminta. Maka, kenaikan harga ekspor akan menyebabkan jumlah minyak sawit yang diminta oleh negara tujuan menurun sehingga volume ekspor juga akan turun.

\section{Estimasi Perhitungan Hambatan NonTarif}

Adanya perdagangan internasional pada dasarnya memudahkan negara untuk saling bermitra dalam jual beli komoditas tertentu. Namun, seiring dengan semakin rendahnya tarif impor antara negara, hambatan perdagangan non-tarif pun diterapkan dengan berbagai tujuan. Perlindungan terhadap industri domestik menjadi salah satu tujuan diberlakukannya hambatan perdagangan di suatu negara. Selain itu, hambatan perdagangan juga seringkali diterapkan untuk melindungi konsumen dari produk berbahaya atau produk yang tidak memenuhi standar suatu negara (Sekretariat Ditjen PPI Kementerian Perdagangan \& ITAPS FEM IPB, 2017).

Perhitungan hambatan nontarif pada penelitian ini menggunakan negara dengan selisih volume ekspor aktual terbesar dengan volume ekspor potensialnya sebagai benchmark, yakni ekspor Indonesia ke Negara Uni Emirat Arab seperti dilakukan oleh Sari (2014) dan Anggoro (2016). Selisih volume ekspor aktual terhadap volume ekspor potensial yang besar menunjukkan arus perdagangan yang lancar dan hambatan perdagangan yang rendah. Oleh sebab itu, negara tersebut relevan untuk dijadikan benchmark pada penelitian (Tabel 10).

Tabel 10. Rata-rata Ekuivalen Tarif Negara OKI terhadap Minyak Sawit Indonesia Tahun 2013-2017

\begin{tabular}{|c|c|}
\hline Negara & Ekuivalen Tarif \\
\hline Afghanistan & $-15,57$ \\
\hline Algeria & 17,56 \\
\hline Bangladesh & 10,29 \\
\hline Benin & 19,67 \\
\hline Brunei Darussalam & 16,87 \\
\hline Burkina Faso & 17,53 \\
\hline Kamerun & 2,49 \\
\hline Gabon & 16,77 \\
\hline Gambia & 17,20 \\
\hline Guinea & 12,32 \\
\hline Guinea-Bissau & 16,84 \\
\hline Iran & 16,83 \\
\hline Yordania & 5,80 \\
\hline Malaysia & 15,76 \\
\hline Maldives & 16,71 \\
\hline Mauritania & 16,99 \\
\hline Mesir & 16,26 \\
\hline Nigeria & 16,67 \\
\hline Oman & 14,71 \\
\hline Pakistan & 16,05 \\
\hline Pantai Gading & 15,62 \\
\hline Saudi Arabia & 16,64 \\
\hline Senegal & 14,88 \\
\hline Sierra Leone & 13,97 \\
\hline Tunisia & 13,82 \\
\hline Turki & 18,89 \\
\hline Togo & 16,43 \\
\hline Uni Emirat Arab & 0,00 \\
\hline
\end{tabular}

Sumber: Hasil Olah Data. 
Benin sebagai negara dengan hambatan nontarif paling besar menekankan pada hambatan conformity assessment related to Sanitary and Phytosanitary (SPS), baik dalam bentuk sertifikasi, inspeksi, dan pengujian. Selain itu Benin juga merupakan negara Afrika Barat yang memproduksi minyak sawit meskipun mayoritas produksi masih dilakukan dalam skala yang kecil dan secara tradisional. Benin juga menerapkan hambatan price control berupa adanya biaya verifikasi dan pajak penilaian untuk kontrol pengemasan semua produk yang berasal dari pertanian 4 .

Burkina Faso menjadi negara OKI dengan nilai hambatan nontarif yang relatif besar. Berdasarkan informasi pada ITIP WTO, Burkina Faso menerapkan beberapa bentuk hambatan nontarif terhadap komoditas minyak sawit, di antaranya price control measures, hambatan SPS dalam bentuk pendekatan sistem, sertifikasi, dan inspeksi. Kontrol harga yang diterapkan oleh Burkina Faso untuk melindungi industri minyak biji kapas domestik yang pada awalnya kalah saing dengan minyak impor yang berasal dari kawasan Asia, salah satunya minyak sawit.

Gambia memiliki otoritas mengenai kualitas dan keamanan pangan yang menyebabkan Gambia menerapkan beberapa hambatan nontarif terhadap produk yang akan masuk. Pada hambatan SPS, Gambia menitikberatkan regulasi pada batas toleransi untuk residu atau kontaminasi oleh zat non-mikrobiologi dengan adanya batas maksimum yang ditetapkan oleh Codex Alimentarius Commisions mengenai kontaminan residu pestisida atau kandungan zat kimiawi lainya. Gambia juga melarang adanya zat-zat pewarna aditif dan membatasi jenis zat-zat pewarna yang boleh digunakan apabila warna alami hilang dalam pemrosesan atau untuk tujuan standarisasi harga. Selain SPS, Gambia juga menerapkan hambatan Technical Barriers to Trade (TBT), berupa TBT measures, dan persyaratan pengemasan.

Nigeria sebagai salah satu negara produsen minyak sawit di Afrika memiliki organisasi dalam mengontrol makanan dan obat-obatan yang akan diimpor ataupun diekspor, yakni National Agency for Food and Drug Administrations and Control (NAFDAC). Berdasarkan ITIP WTO, regulasi yang dibuat oleh NAFDAC lebih menitikberatkan pada hambatan SPS, yakni fortifikasi zat-zat yang terkandung dalam bahan makanan. Selain itu, Nigeria juga mewajibkan prosedur produksi dengan sistem Hazard Analysis Critical Control Point (HACCP) \& Good Manufacturing Practices (GMP) yang terkait dengan keamanan dan keselamatan konsumen.

$4 \quad$ Integrated Trade Intelligence Portal (ITIP WTO). Tersedia pada https://i-tip.wto.org, diunduh pada Maret 2019.
Berdasarkan ITIP WTO, Senegal menerapkan beberapa hambatan nontarif dalam bentuk SPS, yakni berupa larangan impor untuk alasan kesehatan, sertifikasi, larangan penggunaan zat-zat tertentu, persyaratan labeling dan persyaratan otorisasi. Selain SPS, Senegal juga menerapkan beberapa hambatan berupa pre-shipment inspection (INSP) berupa persyaratan melewati bea cukai pelabuhan tertentu, dan formalitas inspeksi lainnya terhadap produk tertentu.

Mauritania menerapkan beberapa hambatan SPS dan TBT, yakni berupa sertifikasi, inspeksi, serta kebijakan SPS berupa fumigasi. Sedangkan Guinea yang merupakan negara OKI bagian Afrika dengan hambatan nontarif terkecil jika dibandingkan dengan negara lainnya. Berdasarkan ITIP WTO, kebijakan nontarif yang diterapkan oleh Guinea terhadap minyak sawit Indonesia selain berupa kebijakan SPS, juga berupa inspeksi dalam bentuk persyaratan untuk melewati pelabuhan tertentu.

Malaysia sebagai negara eksportir minyak sawit terbesar kedua setelah Indonesia menerapkan kebijakan yang cukup beragam terhadap produk minyak sawit yang akan masuk. Regulasi mengenai pangan Malaysia ditetapkan oleh Food Safety and Quality Division (FSQD) yang mempunyai kewenangan untuk implementasi dan penegakan Undang-Undang dan regulasi pangan. Lembaga ini secara aktif melaksanakan program-program, di antaranya kesesuaian standar, pengambilan sampel, inspeksi tempat pengolahan makanan, pengendalian impor pangan dan mengeluarkan lisensi bahan pada makanan ${ }^{5}$. Untuk kebijakan yang diterapkan, Malaysia menerapkan hambatan berupa SPS dan TBT. Berdasarkan ITIP WTO, hambatan TBT yang diterapkan oleh Malaysia berupa persyaratan labeling, larangan impor salah satunya terhadap tipe atau kualitas minyak sawit tertentu, persyaratan mengenai kualitas, keamanan, dan kinerja produk, serta persyaratan produksi dan pasca produksi. Malaysia juga menerapkan regulasi berupa larangan penggunaan zat ataupun nutrient tambahan, persyaratan labeling dan pengemasan.

Turki dengan nilai hambatan nontarif terbesar menitikberatkan peraturan impor pada SPS dalam bentuk persyaratan inspeksi yakni berupa prosedur dan prinsip untuk pengawasan, pemeriksaan pembongkaran, dan pengangkutan muatan antarpelabuhan $^{6}$. Selain itu, adanya perjanjian perdagangan bebas antara Malaysia dan Turki (MITI

\footnotetext{
$5 \quad$ Indonesia Technical Requirements Information System (INATRIMS). Tersedia pada inatrims.kemendag.go.id, diunduh pada April 2019.

Integrated Trade Intelligence Portal (ITIP WTO). Tersedia pada https://i-tip.wto.org, diunduh pada Maret 2019.
} 
FTA) yang berlaku sejak tahun 2014 juga menjadi sebuah hambatan bagi minyak sawit Indonesia.

Afganistan merupakan satu-satunya negara dengan nilai hambatan nontarif negatif sebesar -15,57. Hal ini menunjukkan bahwa Afghanistan cenderung tidak menerapkan hambatan nontarif terhadap produk minyak sawit. Hal ini didukung dengan penelitian yang dilakukan oleh Altai Consulting (2015) yang menunjukkan bahwa Afghanistan mengonsumsi minyak sebanyak 420.000 ton yang sebanyak 367.000 ton merupakan impor dari negara lain, salah satunya Indonesia. Sebanyak 82 persen minyak yang diimpor oleh Afghanistan merupakan minyak sawit dengan HS 151190. Tingginya konsumsi minyak sawit di Afghanistan dikarenakan konsumsi ghee yang juga tinggi, di mana minyak sawit merupakan salah satu bahan baku dalam pembuatan ghee.

Berdasarkan ITIP WTO', Pakistan menerapkan hambatan berupa TBT untuk komoditas minyak. Pakistan menitikberatkan pada standarisasi pengemasan, penyimpanan, dan proses transportasi. Hambatan nontarif yang diterapkan oleh Pakistan rendah dikarenakan Pakistan membutuhkan minyak sawit sebagai bahan baku pembuatan ghee untuk dikonsumsi dan diekspor ke Afghanistan. Sementara, Oman menerapkan kebijakan TBT pada banyak produk,

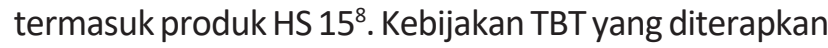
untuk komoditas minyak sawit berupa ketentuan labeling, pengemasan, prosedur penyimpanan, dan proses transportasi, serta batas maksimum lemak trans. Jordan menerapkan hambatan nontarif yang relatif sedikit yakni, kebijakan SPS berupa standar inspeksi dan sampling, dan kebijakan TBT berupa larangan labeling yang berisi informasi yang salah.

Saudi Arabia dengan rata-rata hambatan nontarif sebesar 16,64 persen menerapkan beberapa ketentuan mengenai minyak nabati. Standar yang harus dipenuhi yakni berupa pelabelan, sampling, batas maksimum residu pestisida, pengujian kandungan zat aditif, dan metode penentuan unsurunsur logam yang mencemari bahan pangan. Selain itu, minyak sawit yang akan masuk ke Saudi Arabia juga harus memenuhi beberapa karakteristik, salah satunya yakni bebas dari sedimen dan kekeruhan pada $40^{\circ} \mathrm{C}^{9}$.

Integrated Trade Intelligence Portal (ITIP WTO). Tersedia pada https://i-tip.wto.org, diunduh pada Maret 2019.

8 Integrated Trade Intelligence Portal (ITIP WTO). Tersedia pada https://i-tip.wto.org, diunduh pada Maret 2019.

9 Indonesia Technical Requirements Information System (INATRIMS). Tersedia pada inatrims.kemendag.go.id, diunduh pada April 2019.
Hasil rata-rata perhitungan hambatan nontarif di negara OKI terhadap minyak sawit Indonesia relatif lebih rendah jika dibandingkan dengan hasil penelitian yang dilakukan oleh Callaghan \& Uprasen (2008) yang menunjukkan rata-rata hambatan nontarif untuk komoditas minyak nabati pada negara EU15 dan CEECs-10 adalah 108,64 dan 75,66. Rendahnya nilai ekuivalen tarif ini menunjukkan bahwa hambatan nontarif yang dikenakan pada produk minyak sawit yang diekspor ke negara OKI merupakan sebuah peluang bagi Indonesia untuk bisa meningkatkan kinerja ekspornya ke negara-negara OKI. Salah satu usaha yang dapat dilakukan oleh pemerintah adalah dengan melakukan perjanjian Free Trade Agreements (FTA) dengan sejumlah negara OKI. Hingga saat ini, perjanjian perdagangan bilateral yang telah berjalan adalah Indonesia-Pakistan Free Trade Agreement, sedangkan Indonesia-Turkey FTA dan IndonesiaTunisia PTA masih dalam tahap negosiasi. Kerja sama perdagangan dapat memengaruhi keketatan regulasi maupun tarif bea masuk yang diberlakukan oleh negara tujuan. Salah satu akibat kurangnya kerja sama antara Indonesia dengan negara-negara OKI menyebabkan ekspor minyak sawit Indonesia kalah saing dengan negara-negara lain disebabkan masih tingginya tarif yang diberlakukan oleh negara tujuan.

Penyelarasan regulasi juga perlu dilakukan guna meningkatkan kinerja ekspor Indonesia ke negara OKI, salah satunya terkait penyelarasan sistem pembayaran, dan sulitnya menjalin kontrak pembelian akibat terbatasnya bank yang menyediakan layanan pembiayaan ke negara nontradisional, seperti Afrika dan Timur Tengah (GAPKI, 2019). Ketidakselarasan sistem pembayaran antara Indonesia dengan negara OKI yang mayoritas merupakan negara Afrika dan Timur Tengah ini dapat menjadi hambatan perdagangan berupa finance measures sebagaimana dalam klasifikasi nontariff measures (NTMs) oleh United Nations Conference on Trade and Development (UNCTAD).

Sertifikasi minyak sawit juga dapat menjadi salah satu daya tarik bagi negara tujuan. Adanya isu mengenai minyak sawit Indonesia yang diberlakukan oleh Eropa menunjukkan bahwa Indonesia juga perlu penyelarasan antara standarisasi nasional dan internasional agar produk minyak sawit Indonesia dapat diterima di pasar internasional. Hingga saat ini, Indonesia Sustainable Palm Oil (ISPO) merupakan standar minyak sawit yang diberlakukan di Indonesia yang diharapkan mampu mengurangi dampak kerusakan lingkungan atau deforestasi yang wajib dimiliki bagi perusahaan minyak sawit di Indonesia. Sementarasecarainternasional, sertifikasiRoundtable Sustainable Palm Oil (RSPO) merupakan sertifikasi internasional yang bertujuan untuk mewujudkan 
minyak sawit yang berkelanjutan melalui standarisasi internasional. Terdapat perbedaan antara ISPO dan RSPO. Terdapat beberapa elemen ISPO yang tidak terdapat dalam RSPO, begitu juga sebaliknya. Sementara, terdapat pula perbedaan mendasar yang dapat menjadi kendala jika dilakukan combined audit. Perbedaan tersebut berupa perbedaan mekanisme pemeringkatan, di mana di RSPO terdapat kategori indikator minor dan indikator mayor, sementara pada ISPO hanya terdapat kategori memenuhi atau tidak memenuhi yang nantinya akan berpengaruh pada closing meeting. Untuk itu, diperlukan penyelarasan standardisasi agar produk minyak sawit Indonesia dapat diterima secara internasional, khususnya di negara OKI guna mempertahankan nilai ekuivalen tarif yang rendah.

\section{KESIMPULAN}

Berdasarkan hasil dan pembahasan serta tujuan dari penelitian ini, maka minyak sawit Indonesia memiliki daya saing yang cukup tinggi di negara OKI. Pada 15 negara OKI, minyak sawit Indonesia berada pada posisi rising star yang mengindikasikan bahwa minyak sawit Indonesia memiliki daya saing yang kuat pada 15 negara tersebut. Sedangkan, minyak sawit Indonesia pada 13 negara OKI lainnya menempati posisi falling star, lost opportunity, dan retreat. Hal ini disebabkan oleh beberapa faktor, di antaranya adalah adanya beberapa negara OKI yang juga merupakan produsen dari minyak sawit, serta adanya eksportir baru di negara tujuan.

Hasil estimasi dengan menggunakan analisis regresi data panel menunjukkan bahwa variabel PDB per kapita negara importir, jarak ekonomi antara negara eksportir dan negara importir, harga ekspor, populasi negara importir, serta nilai tukar riil negara eksportir terhadap negara importir berpengaruh signifikan terhadap volume ekspor minyak sawit Indonesia. Variabel yang paling berpengaruh terhadap volume ekspor minyak sawit Indonesia ke negara OKI adalah PDB per kapita negara importir dengan nilai koefisien estimasi terbesar.

Hasil perhitungan hambatan nontarif menunjukkan bahwa secara keseluruhan hambatan nontarif yang diberlakukan oleh negara OKI masih tergolong rendah dengan nilai rata-rata hambatan sebesar 108,54 dan 75,66 . Nilai rata-rata ekuivalen tertinggi untuk negara OKI dengan menggunakan Uni Emirat Arab sebagai negara benchmark adalah Negara Benin dengan nilai ekuivalen tarif sebesar 19,67. Rendahnya nilai ratarata ekuivalen tarif mengindikasikan bahwa Indonesia memiliki potensi dalam meningkatkan ekspornya ke negara OKI yang juga harus diikuti dengan penyesuaian standar negara tujuan.
Berdasarkan hasil perhitungan Export Product Dynamics (EPD), minyak sawit Indonesia berada pada posisi rising star di ke 15 negara OKI dan 13 negara berada di posisi lost opportunity, falling star, dan retreat. Oleh sebab itu, perlu dilakukan upaya guna mempertahankan posisi rising star melalui berbagai upaya, salah satunya adalah menjaga kualitas minyak sawit. Selain itu diharapkan Indonesia juga mampu melakukan peningkatan pangsa produk ekspor di 13 negara lainnya melalui peningkatan efisiensi dan kualitas produk serta peningkatan infrastruktur ekspor. Peningkatan kualitas dapat dilakukan dengan memenuhi standar ISPO secara nasional, maupun sertifikasi internasional seperti RSPO. Bahkan beberapa negara mensyaratkan seritifikat halal.

Sedangkan berdasarkan hasil estimasi, diperoleh jarak ekonomi memiliki koefisien terbesar. Hal ini menunjukkan bahwa, perlu adanya bentuk efisiensi dalam biaya transportasi yang diproksikan dengan jarak ekonomi. Efisiensi biaya transportasi dapat dicapai dengan perbaikan infrastruktur ekspor berupa infrastruktur transportasi seperti pelabuhan, jalan, maupun hub ekspor guna mempermudah distribusi ekspor ke negara OKI.

Belum tersedianya hub ekspor di kawasan Afrika, Asia Selatan, dan Timur Tengah juga menjadi hambatan perdagangan bagi Indonesia untuk meningkatkan ekspornya ke kawasan non-tradisional. Hingga saat ini, Indonesia masih menjadikan Belanda sebagai hub ekspor kawasan Eropa untuk juga menjadi hub ekspor kawasan Afrika Utara. Untuk itu diharapkan Indonesia mampu membuka hub ekspor kawasan Afrika, Asia Selatan, dan Timur Tengah guna meningkatkan kinerja ekspor Indonesia ke negara OKI.

Inisiasi kerja sama multilateral dan bilateral antara Indonesia dengan negara OKI, baik dalam bentuk PTA ataupun FTA, guna meningkatkan kinerja ekspor minyak sawit Indonesia melalui fasilitasi perdagangan dan harmonisasi regulasi seperti mengatasi hambatan berupa tarif bea masuk yang tinggi dan hambatan bea lainnya seperti para-tariff measures atau penyelarasan sistem pembayaran sehingga dapat menigkatkan kinerja ekspor dan daya saing di negara tujuan. 


\section{DAFTAR PUSTAKA}

\section{Buku}

Basri, F. \& Munandar, H. (2010). Dasar-dasar ekonomi internasional. Jakarta: Prenada Media Grup.

Esterhuizen, D. (2006). An evaluation of the competitiveness of the South African Agribusiness Sector. Pretoria: University of Pretoria.

Salvatore, D. (2007). International economics. 9 $9^{\text {th }}$ Edition. New York: John Wiley \& Sons Inc.

\section{Jurnal dan Working Paper}

Anggoro, R., \& Widyastutik. (2016). Non-tariff barrier and factors that influence the Indonesian cocoa export to Europe. Signifikan: Jurnal IImu Ekonomi, 5(1), 1-14.

Asikin, Z., Daryanto, A., \& Anggraeni, L. (2016). Pengaruh infrastruktur dan kelembagaan terhadap kinerja ekspor agregat dan sektoral di Indonesia. Jurnal Manajemen dan Agribisnis, 3(12), 145-156.

Ernawati, Fatimah, Arshad, M., Shamsudin, M.N., \& Mohamed, Z.A. (2006). AFTA and its implication to the export demand of Indonesian palm oil. Jurnal Agro Ekonomi, 24(2), 115-132.

Sari, A.R., Hakim, D.B., \& Anggraeni, L. (2014). Analisis pengaruh non tariff measures komoditi Crude Palm Oil (CPO) Indonesia ke negara tujuan ekspor utama. Jurnal Ekonomi dan Kebijakan Pembangunan, 3(2), 111-135.

Sari, K.R., \& Widyastutik. (2015). Faktor yang mempengaruhi dan estimasi ekuivalen tarif NTBs ekspor kayu lapis Indonesia. Buletin IImiah Litbang Perdagangan, 9(1), 95-108.

Zarzoso, I.M. \& Lehmann, F.N. (2003). Augmented Gravity Model: An empirical application to Mercosur-European Union trade flow. Jurnal of Applied Economics, 6, 291-316.

\section{Skripsi}

Anggoro, R. (2016). Hambatan non tarif dan faktorfaktor yang memengaruhi ekspor kakao Indonesia ke Pasar Uni Eropa. Skripsi. Bogor: Institut Pertanian Bogor.
Samosir, M.A. (2015). Analisis daya saing dan faktorfaktor yang memengaruhi ekspor kopi Indonesia ke negara tujuan ekspor. Skripsi. Bogor: Institut Pertanian Bogor.

Sari, K.R. (2014). Daya saing, hambatan non-tarif dan faktor-faktor yang memengaruhi ekspor kayu lapis Indonesia ke negara tujuan ekspor utama. Skripsi. Bogor: Institut Pertanian Bogor.

\section{Laporan}

Altai Consulting. (2015). Afghanistan/Central Asia regional food foritfication program, trade flow analysis. Geneva: The Global Alliance for Improved Nutrition (GAIN).

BP3-Kementerian Perdagangan. (2018). Biaya dan manfaat Trade Preferential Tarif System of the Organization of Islamic Cooperation (TPS-OIC). Jakarta: Kementerian Perdagangan.

Sekretariat Ditjen PPI Kementerian Perdagangan \& ITAPS FEM IPB. (2018). Penyusunan strategi kebijakan non tarif dan penurunan hambatan non tarif. Jakarta: Kementerian Perdagangan dan IPB.

\section{Makalah}

Callaghan, B.A. \& Uprasen, U. (2008). Impact of $5^{\text {th }}$ enlargement on ASEAN. Paper presented at the EcoMod International Conference on Policy Modeling Berlin, Germany $2^{\text {nd }}-4^{\text {th }}$ July 2008.

Lam N.T., Yet H.T., Hai L.T., Huong P.T., Ha N.T., \& Huan T.T. (2001). Effects of red palm oil supplementation on vitamin $A$ and iron status of rural underfive children in Vietnam. Paper in: Cutting-Edge Technologies for Sustained Competitiveness Food Technology and Nutrition Conference. Proceedings 2001 PIPOC International Palm Oil Congress; Malaysia, 2022 August 2001. Malaysian Palm Oil Board, Malaysia.

\section{Sumber Lainnya}

GAPKI. (2019). Eksportir CPO telah jajaki pasar baru, namun sulit jalin kontrak. Diunduh tanggal 01 Mei 2019, dari gapki.id/news. 